\title{
Effect of PV Orientation on Energy Generation and Economy: A Case Study for Istanbul-Turkey
}

\author{
[ Ali Durusu, Ali Erduman. Mugdesem Tanrioven ]
}

\begin{abstract}
This analysis consider the effect of azimuth angle of fixed photovoltaic (PV) system on energy generation of PV system. Detailed PV production model, including effect of solar radiation, temperature and wind speed, was used to calculate output of PV array for different azimuth angles of PV array. For determination of economic value of the PV produced power, daily electricity price variation of Turkey was also considered. A comparison between the produced power and economic value of produced power of different azimuth angle was performed. The results obtained from comparison are presented and discussed.
\end{abstract}

Keywords - economic value, effect of orientation, energy generation, PV array

\section{Introduction}

Renewable energy sources utilization has been rapidly increasing for the last two decades because of reducing fossil based energy generation and environmental hazards [1]. Especially the photovoltaic (PV) systems have begun to be used frequently in order to meet the quickly increasing energy demand [2]. PV system, which can be stand-alone installed for providing electricity in some distant areas or be connected to grid for selling power, is the main technology to transform solar energy into electric power [3].

For optimal design of PV systems, it is important to define system performance at the location of application [4]. The amount of power produced by PV system contingent upon the solar radiation, tilt angle, azimuth angle and environmental effects. Alternative consideration for optimal location of PV system is economic-value of the electricity produced. Because PV system energy generation does not align with grid load [5]. So, the PV production based placement might not be optimal for economic value of the price of electricity produced. Electricity price might be shifted to the optimal positioning to further west of south. Economic value based investigation summarized in a national level by [6].

This analysis considers the effect of azimuth angle of fixed photovoltaic (PV) system on their total energy generation. Detailed PV production model, including effect of solar radiation, temperature and wind speed, was used to calculate output of PV array for different azimuth angles of PV array. For determination of economic value of the PV produced power, daily electricity price variation of Turkey was also considered. A comparison between the produced power and economic value of produced power of different azimuth angle was performed. The results obtained from comparison are presented and discussed.

Ali Durusu, Ali Erduman, Mugdesem Tanrioven

Yildiz Technical University

Turkey

\section{Methods}

This analysis uses solar radiation and electricity price data to (1) determine the available solar radiation on a given plane, (2) built a PV production model and (3) economic value of PV produced power. The region considered to determine the effect of orientation on PV energy generation is Istanbul (Lat:41.02, Long:29.02). Optimum tilt angle is taken as $27^{\circ}$ and azimuth angles are chosen as; east:-90 south-east:- $45^{\circ}$, south: $0^{\circ}$, south-west: $45^{\circ}$ and west: $90^{\circ}$.

\section{A. Available Solar Radiation on a Plane}

The measured solar radiation on the earth's surface (global radiation) is lower than extraterrestrial radiation due to the various effects of the atmosphere. The main effect is that $30 \%$ of incoming solar radiation is reflected back into space by the atmosphere [7]. Total radiation reached to the earth`s surface is sum of direct $\left(I_{b}\right)$ and diffused radiation $\left(I_{d}\right)$ as given in (1)

$I=I_{b}+I_{d}$

Separation of global radiation into direct and diffused components can be calculated by empirical formulas which are developed as a function of clearness index $\left(k_{T}\right)$ as given in (2). Clearness index (3) is described as function of the global radiation and extraterrestrial radiation.

$$
\begin{aligned}
& \frac{I_{d}}{I}=\left\{\begin{array}{cc}
1-0.09 k_{T} & k_{T} \leq 0.22 \\
0.9511-0.1604 k_{T}+4.388 k_{T}{ }^{2}-16.638 k_{T}{ }^{3}+12.336 k_{T}{ }^{4} & 0.22 \leq k_{T} \leq 0.80 \\
0.165 & k_{T}>0.80
\end{array}\right. \\
& k_{T}=\frac{I_{o}}{I}
\end{aligned}
$$

Total radiation on a tilted plane is sum of the direct, diffused and reflected radiation as given in (4) [8].

$I_{T}=I_{b} R_{b}+I_{d}\left(\frac{1+\cos \beta}{2}\right)+I \rho\left(\frac{1-\cos \beta}{2}\right)$

where $\beta$ is the plane tilt angle, $\rho$ is ground albedo (0.2) and $R_{b}$ is the direct radiation ratio coefficient. $R_{b}$ is given in (5) [9].

$R_{b}=\frac{\cos \theta}{\cos \theta_{Z}}$

where $\theta$ is radiation incident angle and $\theta_{Z}$ is zenith angle.

\section{B. PV Production Model}

PV production model was built to estimate PV production from solar radiation considering cell temperature 
and wind speed. General model of PV production is given in (6) [10].

$$
P_{p v}=\eta_{p v} x \eta_{o t h e r} x I_{T}
$$

where $P_{p v}$ is PV production for per square meter $\left(\mathrm{W} / \mathrm{m}^{2}\right)$, $\eta_{p v}$ is PV array efficiency and $\eta_{o t h e r}$ is other derate factor (mismatch, connection, etc., taken as 0.93). PV array efficiency is given in (7) [5].

$\eta_{p v}=\eta_{r e f}\left[1-\beta_{r e f}\left\{T_{a}-T_{r e f}+T_{c}-T_{N}\left(\frac{I_{T}}{I_{N}}\right)\right]\right.$

where $\quad \eta_{\text {ref }}$ is reference efficiency $(12 \%), \beta_{\text {ref }}$ is temperature coefficient $(0.0045)$ of $\mathrm{PV}$ array [11], $T_{a}$ is ambient temperature, $T_{r e f}$ is reference temperature $\left(25^{\circ} \mathrm{C}\right)$, $T_{c}$ PV cell temperature, $T_{N}$ is nominal operating condition temperature $\left(20^{\circ} \mathrm{C}\right)$ and $I_{N}$ is incident radiation $\left(800 \mathrm{~W} / \mathrm{m}^{2}\right)$ at nominal operating condition [10]. PV cell temperature is given in (8) [12].

$T_{c}=1.14\left(T_{a}-T_{r e f}\right)+0.0175\left(I_{T}-300\right)-k_{r} \omega_{s}+30(8)$ where $k_{r}$ is wind speed coefficient (taken as 1.509) and $\omega_{s}$ is wind speed $(\mathrm{m} / \mathrm{s})$. Fig. 1 shows global radiation, ambient temperature and wind speed variation during the year for Istanbul-Turkey [5].
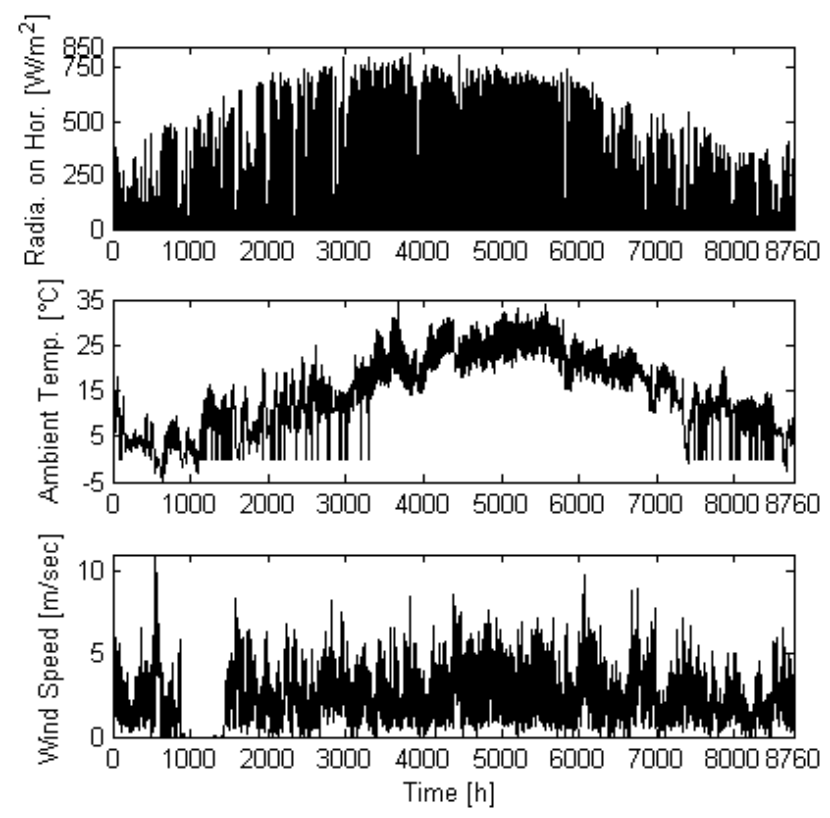

Figure 1. Global solar radiationon horizontal plane, ambient temperature and wind speed variation during the year

\section{Economic Value Model}

Economic value of PV produced power is determined considering daily electricity price variation of Turkey including all taxes as given in (9) [5]. $p(t)=\left\{\begin{array}{l}p_{p}, t \in T_{p}, T_{p}=[17,22) \\ p_{o}, t \in T_{o}, T_{o}=[22,6) \\ p_{s}, t \in T_{s}, T_{s}=[6,17)\end{array}\right.$

where $p_{p}=0.21538 \$ / \mathrm{kWh}$ is the electricity price for the peak load period, $p_{o}=0.07692 \$ / \mathrm{kWh}$ is the electricity price for the off-peak period and $p_{s}=0.14231 \$ / \mathrm{kWh}$ is the electricity price for the standard period. Total income of selling electricity is calculated as given in (10).

$M=\sum_{d=1}^{365} \sum_{t=1}^{24} p(t) x P_{p v}(t)$

where $d$ is day number of a year (1-365).

\section{Results and Discussion}

The amount of PV power generated by the PV array is affected by solar radiation, temperature and wind speed. Based on (1-5), the total solar radiation falling on PV array, which is oriented at different azimuth angle, is determined. The monthly solar radiation (for per square-meter surface) for the inclined surface at the optimal angle (tilt:27 $)$, and the five vertical surfaces facing east, south-east, south-west and west were determined and presented in Figure 7.

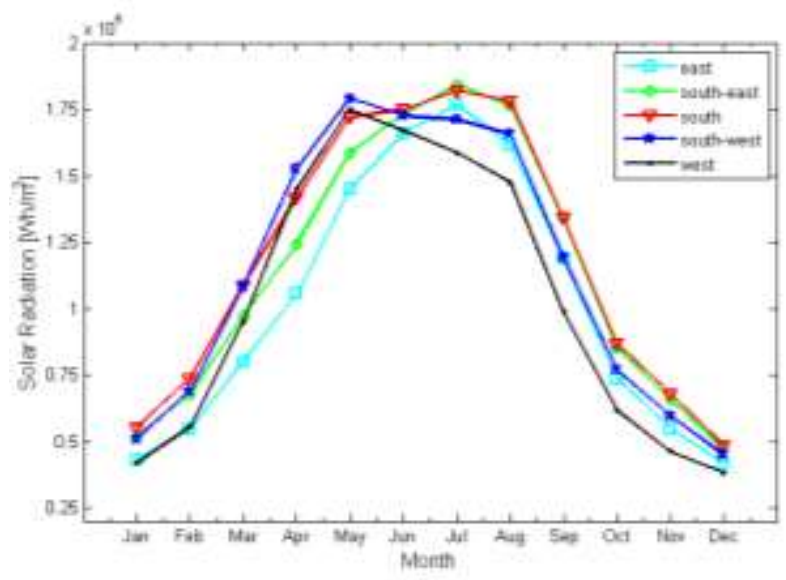

Figure 2. Mothly total radiation for different orientation (tilt: $27^{\circ}$ and azimuth: east $=-90^{\circ}$, south-east $=-45^{\circ}$, south $=0^{\circ}$, south-west $=45^{\circ}$, west $=90^{\circ}$ )

Monthly profile of solar radiation is for different orientation is similar. South-west and west oriented surface receive largest solar radiation on April. East, south-east and south oriented surfaces are received the largest solar radiation on June. The low solar radiation for all surfaces obtained from December to January.

Based on (6-8), PV array (one square-meter) productions for 5 different azimuth angles are determined. Fig. 3 displays the daily average PV array production for seasons. 


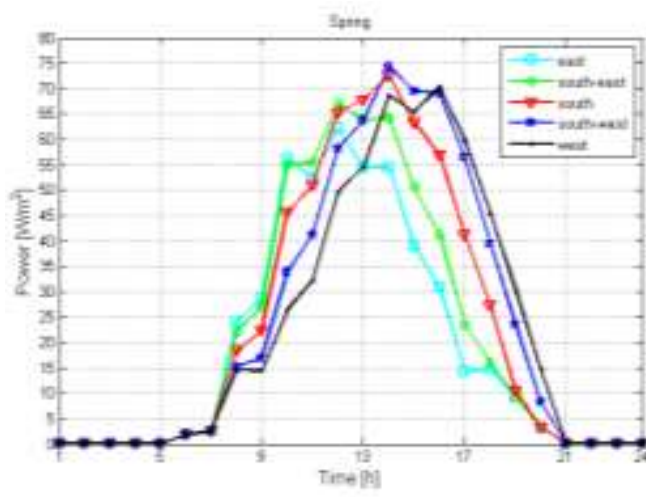

a

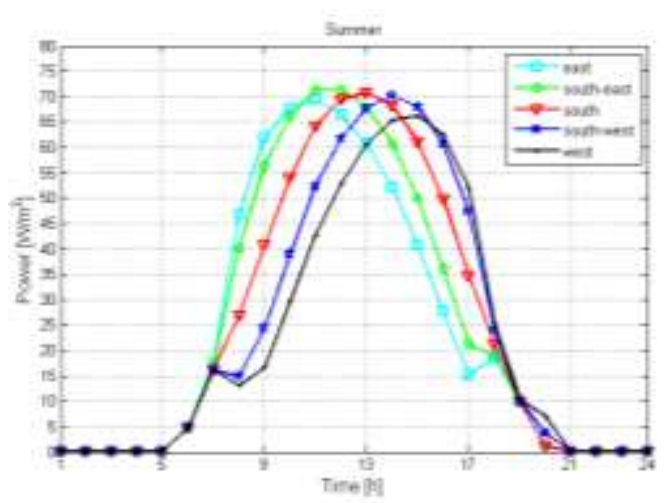

b

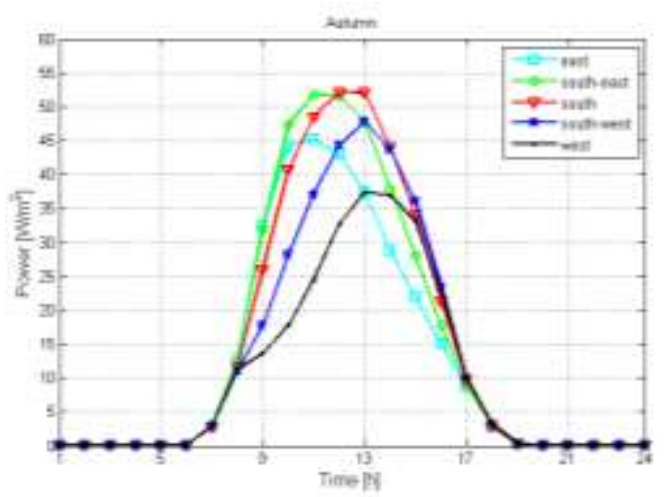

$\mathrm{c}$

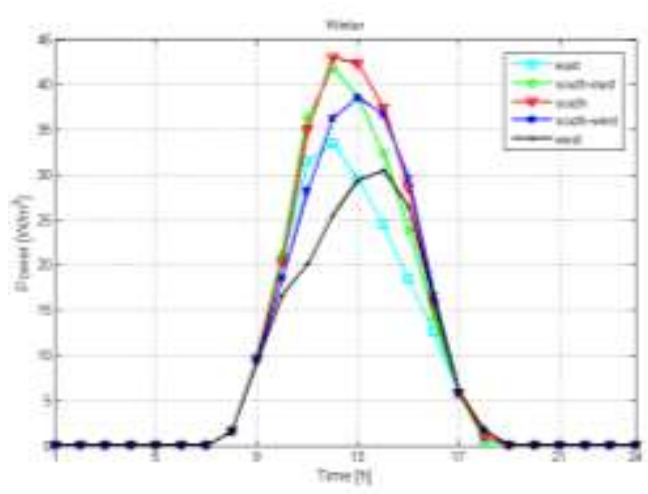

d

Figure 3. Daily average PV production for different season (tilt: $27^{\circ}$ and azimuth: east $=-90^{\circ}$, south-east $=-45^{\circ}$, south $=0^{\circ}$, south - west $=45^{\circ}$, west $=90^{\circ}$ )
It is clear from the Fig. 3 that when PV azimuth angle is deviated from south to east, PV production increases during the morning hours. However, when PV azimuth angle deviate from south to west, PV production increases during the afternoon hours. Total PV productions for different orientation during the year are given in Table I. South orientated PV array production has highest value for all season and east orientated PV array production in spring and west orientated PV array in the other seasons has lowest value. It is also clear from Table I that, when south orientated PV production is chosen as base, energy differences value is lowest at east orientation in spring and west orientation in the other seasons. Energy differences value is highest at west orientation in spring, south-west orientation in summer and south-east orientation in autumn and winter.

TABLE I

TOTAL ENERGY AND TOTAL INCOME

\begin{tabular}{|c|c|c|c|c|c|}
\hline $\begin{array}{c}\text { Seas } \\
\text { on }\end{array}$ & $\begin{array}{c}\text { Orie } \\
\text { ntati } \\
\text { on }\end{array}$ & $\underset{\left[\mathrm{kWh} / \mathrm{m}^{2}\right]}{\text { Energy }}$ & $\begin{array}{c}\text { Energy } \\
\text { Differences } \\
{[\%]}\end{array}$ & $\begin{array}{c}\text { Total } \\
\text { Incom } \\
\text { e [\$] }\end{array}$ & $\begin{array}{c}\text { Income } \\
\text { Differences } \\
{[\%]}\end{array}$ \\
\hline \multirow{5}{*}{ 告 } & $-90^{\circ}$ & 37.161 & -21.996 & 5.552 & -24.028 \\
\hline & $-45^{\circ}$ & 42.841 & -10.072 & 6.427 & -12.044 \\
\hline & $0^{\circ}$ & 47.639 & 0 & 7.308 & 0 \\
\hline & $45^{\circ}$ & 46.695 & -1.982 & 7.881 & 7.847 \\
\hline & $90^{\circ}$ & 46.753 & -1.860 & 7.585 & 3.802 \\
\hline \multirow{5}{*}{ 离 } & $-90^{\circ}$ & 51.592 & -5.559 & 7.642 & -7.088 \\
\hline & $-45^{\circ}$ & 54.594 & -0.064 & 8.115 & -1.345 \\
\hline & $0^{\circ}$ & 54.629 & 0 & 8.225 & 0 \\
\hline & $45^{\circ}$ & 51.990 & -4.831 & 7.971 & -3.095 \\
\hline & $90^{\circ}$ & 48.255 & -11.668 & 7.503 & -8.777 \\
\hline \multirow{5}{*}{ 拦 } & $-90^{\circ}$ & 26.843 & -14.637 & 3.898 & -14.522 \\
\hline & $-45^{\circ}$ & 31.065 & -1.212 & 4.500 & -1.316 \\
\hline & $0^{\circ}$ & 31.446 & 0 & 4.560 & 0 \\
\hline & $45^{\circ}$ & 27.803 & -11.587 & 4.047 & -11.263 \\
\hline & $90^{\circ}$ & 22.395 & -28.785 & 3.280 & -28.074 \\
\hline \multirow{5}{*}{ 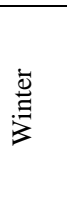 } & $-90^{\circ}$ & 16.785 & -21.647 & 2.429 & -21.453 \\
\hline & $-45^{\circ}$ & 20.150 & -5.943 & 2.908 & -5.969 \\
\hline & $0^{\circ}$ & 21.423 & 0 & 3.093 & 0 \\
\hline & $45^{\circ}$ & 19.836 & -7.409 & 2.871 & -7.172 \\
\hline & $90^{\circ}$ & 16.324 & -23.799 & 2.371 & -23.325 \\
\hline
\end{tabular}

Economic value of PV produced power considering (910) are given in Table I. Total income is highest at southwest orientated PV array in spring and south orientated PV array in the other season. Total income value is lowest at east orientated PV array in spring and west orientated PV array in the other seasons. Total income difference values have same order with total income value.

Because of the electricity selling price is not constant during the day, energy differences and income differences are not same. In east and south-east orientation, income differences are increased comparing to the energy differences because of the large part PV production is generally in morning hours (standard period). However in south-west and west orientation, income differences are decreased comparing to the energy differences because of the large part of PV production is generally in afternoon hours (standard and peak period). Fig. 4 displays the daily average PV array production for one year. 
Proc. of the Third Intl. Conf. on Advances in Mechanical and Automation Engineering - MAE 2015.

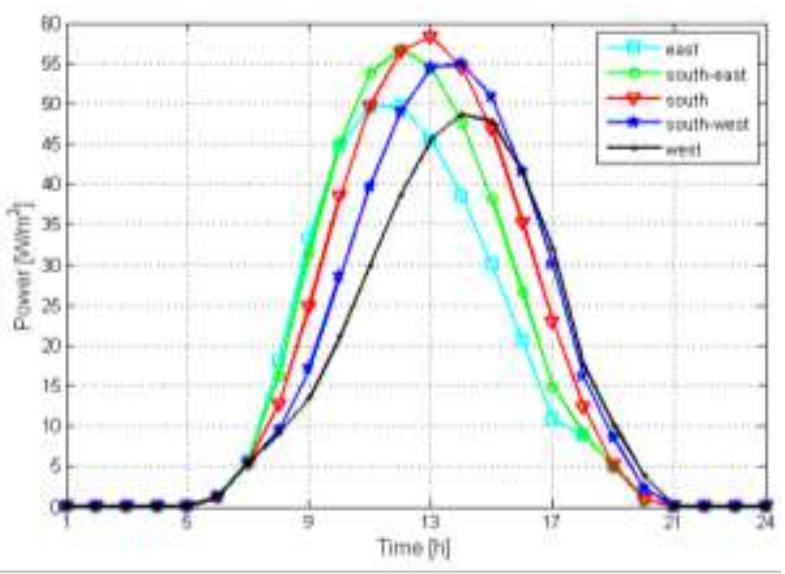

Figure 4. Daily average PV production for one year (tilt: $27^{\circ}$ and azimuth: east $=-90^{\circ}$, south-east $=-45^{\circ}$, south $=0^{\circ}$, south-west $=45^{\circ}$, west $=90^{\circ}$ )

Generally, the energy output values of PV array decreases with increasing or decreasing the azimuth angles. For a given tilt angle $\left(27^{\circ}\right)$, PV panels oriented to south always generate the largest energy outputs except from south-west and west orientation in spring.

\section{Conclusion}

The effect of PV orientation on energy output and unit energy cost of PV system are analyzed. The whole year 1 hour recorded horizontal solar radiation, temperature and wind speed data is used for analysis. The incident solar radiations on various orientated surface are calculated. The surface tilt angle is taken as $27^{\circ}$. The monthly solar radiation results demonstrated that the amount of solar radiation received by surface mounted on different orientations are similar. However the radiation is reached to highest and lowest value at different month in a year. Daily average PV production results show that when PV azimuth angle is deviated from south to east, PV production increases during the morning hours. However, when PV azimuth angle deviate from south to west, PV production increases during the afternoon hours. PV production results show that optimum orientation for all season is south. However the total income values show that the optimum orientation in spring and the other season are south-west and south respectively.

\section{References}

[1] O. Arikan, E. Isen, A. Durusu, B. Kekezoglu, A. Bozkurt, A. Erduman, "Introduction to hybrid systems-Yildiz Technical University," IEEE Eurocon 2013 Conference; 1-4 July 2013; Zagreb, Croatia; IEEE. pp. 1145-1149.

[2] B. Kekezoglu, O. Arikan, A. Erduman, E. Isen, A. Durusu, A. Bozkurt, "Reliability analysis of hybrid energy systems: Case study of Davutpasa Campus," IEEE Eurocon 2013 Conference; 1-4 July 2013; Zagreb, Croatia; IEEE. pp. 1141-1144.

[3] W. Zhou, T. Henerica, X. Xiaohua, "Demand side management of photovoltaic-battery hybrid system," Applied Energy, vol. 148, pp. 294-304, 2015.

[4] K. Murat, S. Mehmet, B. Yunus, D. Sedat, "Determining optimum tilt angles and orientations of photovoltaic panels in Sanliurfa, Turkey," Renewable Energy, vol. 29(8), pp. 1265-1275, 2004.

[5] A. Durusu, A. Erduman, M. Tanrioven, W. Gawlik, "Comparative study of PV array optimum tilt and azimuth angles with multi- objective consideration,” Turkish Journal of Electrical Engineering and Computer Sciences, (Under Review).

[6] D.R. Joshua, R.U. Charles, J.C. Wesley, L.H. Chris, E.W. Michael, "A multi-objective assessment of the effect of solar PV array orientation and tilt on energy production and system economics" Solar Energy, vol. 108, pp. 28-40, 2014.

[7] V. Quaschning, "Understanding renewable energy systems," Third Edit. London: Earthscan, 2005.

[8] B.Y.H. Liu, R.C. Jordan, "The long term average performance of flat plate solar energy collectors," Solar Energy, vol. 7, pp. 53-74, 1963.

[9] W. Beckman, J. Duffie, "Solar engineering of thermal proccesses," 3rd. ed. New York, NY, USA: Wiley and Sons, 1980.

[10] D.R. Joshua, R.U. Charles, J.C. Wesley, L.H. Chris, E.W. Michael "A multi-objective 9 assessment of the effect of solar PV array orientation and tilt on energy production and system economics," Solar Energy, vol. 108, pp. 28-40, 2014.

[11] T.T.Chow, "Performance analysis of photovoltaic-thermal collector by explicit dynamic model,” Solar Energy, vol. 75, pp. 143-152, 2003.

[12] M.G. Tamizh, L. Ji, Y. Tang, L. Petacci, "Photovoltaic Module Thermal/Wind Performance: Long-Term Monitoring and Model Development for Energy Rating," NCPV and Solar Program Review Meeting; 2003; Denver, Colorado, USA; pp. 1-4.

About Author (s):

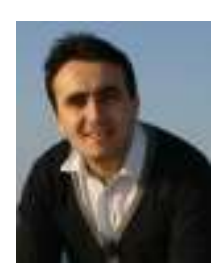

Ali Durusu received the M.Sc. degree in the Department of Electrical Engineering from Yildiz Technical University in 2011, Turkey. He is currently pursuing doctoral study. $\mathrm{He}$ is working as a Research Assistant in the Department of Electrical Engineering, Yildiz Technical University, Turkey.

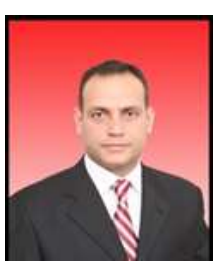

Ali Erduman received the M.Sc. and Phd. degree in Abant Izzet Baysal University 2011 and Yildiz Technical University 2015 respectively in Turkey. He is working as a Research Assistant in the Department of Electrical Engineering, Yildiz Technical University, Turkey.

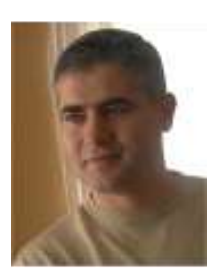

Mugdesem Tanrioven received the $\mathrm{PhD}$. degree in electrical engineering from Yildiz Technical University, Turkey, in 2000. Now, he is with the Electrical Engineering Department of Yildiz Technical University, Turkey. His research areas include renewable energy, power system reliability. 